\title{
Epiphytism on Agarum fimbriatum: can herbivore preferences explain distributions of epiphytic bryozoans?
}

\author{
Kathleen M. Durante*, Fu-Shiang Chia \\ Department of Zoology, University of Alberta, Edmonton, Alberta, Canada T6G 2E9
}

\begin{abstract}
The association between an epiphytic stenolaemate bryozoan, Lichenopora novaezelandiae, its algal host substratum Agarum fimbriatum (Order Laminariales). and an herbivorous snail, Tegula pulligo (Subclass Prosobranchia), was investigated. Field surveys showed that bryozoan age distributions were spatially correlated with algal age distributions: younger bryozoans were concentrated on the youngest parts of the algae, and vice versa. In laboratory experiments, planktonic larvae of this bryozoan displayed a strong preference for $A$. fimbriatum over other kelps, and preferred settling on younger regions of A. fimbriatum over older regions. Although T. pulligo was deterred from feeding on $A$. fimbriatum as compared to other kelps, the snails nonetheless displayed within-thallus discrimination for tissues of different ages of this low-priority food item. Younger tissues, with or without resident epiphytic bryozoans, were consumed in much lower quantities than older tissues. Adult bryozoans on older $A$. fimbriatum deterred feeding by the gastropods, revealing an indirect beneficial effect of epiphytic organisms on their host algal substrata. Previous diet of $T$. pulligo maintained in the laboratory failed to influence significantly the snails's consumption of A. fimbriatum.
\end{abstract}

\section{INTRODUCTION}

Symbioses are widespread throughout aquatic and terrestrial habitats (Davenport 1955). In marine benthic habitats, many invertebrates display remarkable specificity in their associations with other animals or algae (e.g. Ross 1965, Greene 1970, Ross 1971 , Bloom 1975, Stoner 1980, Osman \& Haugsness 1981, Olson 1983, Keough 1986, Paul \& Van Alstyne 1988). These associations are thought to arise not by coincidence, but through evolutionary selection for adaptive consequences of the symbioses. For sessile invertebrates, permanently affixed to a substratum for their entire adult life, associations or symbioses are formed only when dispersing larvae settle on or near their partners. Thus, if strong selection for symbioses occurs among sessile invertebrates, then selective habitat choice by dispersing larvae must be the

\footnotetext{
- Address for correspondence: Bamfield Marine Station
} Bamfield, British Columbia, Canada VoR 1B0 mechanism for bringing associated species together Most of the previous studies examining ecological and evolutionary associations between species concentrate on only 2 associated organisms. In this study, we examined an unusual tripartite association among an epiphytic bryozoan, its kelp substratum, and herbivorous snails.

In Barkley Sound, on Vancouver Island in Canada, we have observed a very close association between the bryozoan Lichenopora novae-zelandiae (Class Stenolaemata: Order Cyclostomata) and its algal substratum, the subtidal kelp Agarum fimbriatum (Class Phaeophyceae: Order Laminariales). Repeated attempts to locate this bryozoan species on other algal substrata and rocks, and among fouling organisms on floating docks, were unsuccessful. On $A$. fimbriatum, we found that younger $L$. novae-zelandiae were concentrated on younger regions of the algal tissue (pers. obs.). Many species of bryozoans are known to settle on the surfaces of marine algae and seagrasses (Stebbing 1972, O'Connor et al. 1979, Seed \& O'Connor 1981, Oswald 
et al. 1984, Keough 1986), and may even derive nutrition from their living substrata (De Burgh \& Fankboner 1978). Although the planktonic larvae of certain bryozoans settle preferentially on older microbial films (Mihm et al. 1981, Maki et al. 1989), the necessary distributional consequence of such a preference (younger bryozoans found on older plant tissue) is rarely observed in the field. Rather, age distributions of epiphytic bryozoans (as inferred from relative colony sizes) appear to reflect the age of the plant substratum: younger bryozoans are found on young plant tissue, and older bryozoans are found on older plant tissue (Stebbing 1972, Roland 1980, Oswald et al. 1984). If, as numerous studies suggest, bryozoan larvae settle preferentially on older microbial films and on younger plant tissue, then there is a puzzling discrepancy in the physical characteristics of substrata that induce bryozoan settlement. Older plant tissue would have to be covered by an older microbial film than is present on younger regions of the same plant, yet the larvae of certain epiphytic bryozoans prefer younger tissue harbouring younger microbial films. These contrasting reports of bryozoan larval preferences suggest that microbial films, although important cues for settlement on inert substrata such as glass (Mihm et al. 1981), wood (Brancato \& Woollacott 1982), and plastic (Mihm et al. 1981, Maki et al. 1989), may have comparatively little influence when larvae are also exposed to cues associated with living substrata. The work presented here focuses on why epiphytic bryozoans settle only on certain algal species and only on certain regions of the algal thallus. In particular, we considered herbivory to be a potentially important selective force directing the settlement of epiphytic bryozoans.

The association of Lichenopora novae-zelandiae with a particular kelp species, and its non-random distribution along kelp blades, prompted us to ask whether selective settlement by the larvae of these bryozoans could explain the observed distribution, and, if so, why this particular distribution might be considered beneficial. Given that Agarum spp. are reported to be avoided by generalist herbivores such as urchins (Vadas 1977, Larson et al. 1980), we proposed that either the same mechanism deterring herbivores from this kelp species may also be attracting epiphytic bryozoans, or there has been selection for a substratum that, historically, herbivores (with potential for incidental damaging or killing epiphytic organisms) have avoided. Here, to address the above questions about an observed symbiotic association, we present data on the distribution of the bryozoan $L$. novaezelandiae along its kelp substratum Agarum fimbriatum, results of bryozoan larval selectivity experiments, and results of herbivore preference tests among and within algal food items.

\section{MATERIALS AND METHODS}

Location. All field work was conducted using SCUBA in 10 to $15 \mathrm{~m}$ of water at Dixon Island in Barkley Sound, Vancouver Island, British Columbia, Canada ( $48^{\circ} 51.24^{\prime} \mathrm{N}, 125^{\circ} 7^{\prime} \mathrm{W}$ ) between May 1990 and February 1991. The subtidal site is characterized by a gently sloping cobble substratum, and it is well protected from storm-induced wave action. Herbivore feeding experiments and bryozoan settlement experiments were conducted in running seawater aquaria.

Epiphyte censuses. The diversity and abundance of epiphytic bryozoans on Agarum fimbriatum were measured by taking samples using a transect line marked in $1 \mathrm{~m}$ intervals, placed through a dense subtidal bed of $A$. fimbriatum in a randomly determined compass direction. The plant whose holdfast was closest to each transect mark was removed from the substratum and carefully placed inside a sealed polyethylene bag until 10 plants had been collected. The $A$. fimbriatum samples were immediately returned to the laboratory and subsampled in the following manner. Based on a preliminary survey of $A$. fimbriatum sizes at Dixon Island, the average length of this species during August 1990 was ca $120 \mathrm{~cm}$ (Durante \& Chia unpubl.). In members of the Laminariales, including $A$. fimbriatum, new blade tissue is added from an intercalary meristem between the stipe and the blade (Bold \& Wynne 1985); thus, plants were divided into three 40 $\mathrm{cm}$ sections in order to sample young, medium, and old A. fimbriatum tissue. Within each algal age category, a cork borer was used to remove 10 disks (area of each disk was $3.03 \mathrm{~cm}^{2}$ ). In this subsampling procedure, 4 disks were cut from each of the left and right halves of the blade, and 2 were cut from the central midrib. The disks were placed in $70 \%$ ethanol for storage and later examined for the presence of bryozoans. Epiphytic animals were not loosened or dislodged during preservation in ethanol, although pigments from the algae were extracted by the solvent. To check the accuracy of our subsampling protocol, an additional $A$. fimbriatum was collected, and all L. novae-zelandiae ancestrulae (one zooid), juveniles or small adults (asexually growing zooids not yet forming a complete circle on the substratum), and adults (circular colonies) were carefully counted.

Bryozoan settlement experiments. To test whether the planktonic larvae of Lichenopora novae-zelandiae actively choose their substrata, we offered a choice of common kelp species at our field site to $L$. novaezelandiae larvae in a laboratory settlement experiment. This experiment also tested larval preferences between young and old tissue of the bryozoan's commonly used substratum, Agarum fimbriatum. Substrata for choice experiments (young A. fimbriatum, 
old A. fimbriatum, Nereocystis luetkeana, and Macrocystis integrifolia) were prepared by cutting circular disks $(1.6 \mathrm{~cm}$ in diameter) from each algal type. For algal species other than A. fimbriatum, intermediate age tissue was selected from the central portion of each frond. Following removal of all epiphytes from the surfaces of the disks, the choice substrata were placed under a jet of running seawater for ca 24 h until mucous discharge from wounded algal tissue ceased. One disk of each choice substratum was placed in each of 10 replicate glass dishes. To avoid bias from unidirectional light in the laboratory, the algal disks were randomly assigned to 1 of 4 positions within the dishes.

To obtain bryozoan larvae, adult colonies of Lichenopora novae-zelandiae were carefully excised from Agarum fimbriatum, and placed in sealed glass dishes containing $1 \mu \mathrm{m}$ filtered seawater. The dishes were kept cool ( $\mathrm{ca} 10^{\circ} \mathrm{C}$ ) by partially submerging them in a flow-through seawater aquarium, and were shaded by covering them with an opaque black plastic bucket for $6 \mathrm{~h}$. Upon removal from darkness, the dishes were placed on ice and illuminated by a $100 \mathrm{~W}$ incandescent bulb, similarly to methods described by Reed (1987). As larvae began swimming out of parental brood chambers, they were pipetted into dishes containing choice substrata. Larvae were not counted individually, but rather were distributed evenly among the 10 dishes by pipetting aliquots of a larval suspension into each dish. The experimental dishes were sealed, partially submerged in a flow-through seawater aquarium, covered with an opaque board, and left undisturbed during the course of the experiment. $L$. novae-zelandiae ancestrulae that had settled on each choice substratum were counted after $24 \mathrm{~h}$ and again after $72 \mathrm{~h}$. These data were analyzed using a nonparametric Friedman test for randomized block experimental designs (Zar 1984).

Herbivore feeding experiments. During our field collections and surveys, the dominant herbivore observed feeding on Agarum fimbriatum was the prosobranch gastropod Tegula pulligo. In a previous study at this field site, $T$. pulligo was observed on both Macrocystis integrifolia and A. cribrosum, and was found to exert considerable grazing damage on $M$. integrifolia (Sharp 1974). As marine prosobranch gastropods have been used with great success in numerous studies addressing palatability of algae and the presence of plant secondary metabolites (e.g. Geiselman \& McConnell 1981, Targett \& McConnell 1982, Steinberg 1984, 1985, Johnson \& Mann 1986), we chose to use the abundant T. pulligo for all herbivore feeding experiments presented here. Snails ranged from 1.8 to $2.9 \mathrm{~cm}$ in shell diameter, and were collected exclusively from the surfaces of $M$. integri- folia and $A$. fimbriatum. During transport from the field to the laboratory, snails were kept submerged in seawater and shaded from sunlight. In the laboratory, $T$. pulligo were fed ad libitum the algae from which they were collected.

We conducted several experiments to test the preferences of snails for the 3 common kelp species present near our field site, Macrocystis integrifolia, Nereocystis luetkeana, and Agarum fimbriatum (Pace 1975, Durante pers. obs.). Although Tegula pulligo is present on a number of different algal surfaces, we were specifically interested in comparing rates of food consumption between $A$. fimbriatum (Agarum spp. are reported to be highly unpalatable; Vadas 1977, Larson et al. 1980, Steinberg 1985) and other more palatable algae. Feeding time among these experiments ranged from 24 to $68 \mathrm{~h}$; this variation was largely due to our prolonging feeding times when low seawater temperatures reduced grazing rates of snails.

First, we compared grazing by Tegula pulligo among the above common algal species. To test rates of grazing on these algae, we placed 0.5 to $1.2 \mathrm{~g}$ blotted wet weight of algae (intermediate age tissue in all cases) and $1 T$. pulligo into 16 replicate flow-through plastic containers $(10.5 \times 10.5 \times 6 \mathrm{~cm})$ which were covered on 3 sides by $2 \mathrm{~mm}$ Nitex ${ }^{\mathrm{rM}}$ mesh. The snails were assigned to treatments randomly, and the mean shell diameter of snails was not found to be different among the 3 treatments (Kruskal-Wallis Test, $0.25<\mathrm{p}<0.50$ ). Four of the containers in each algal treatment were designated as controls, in which snails were confined in VexarTM bags within the plastic containers, allowing them to fertilize the algae but preventing grazing. As each replicate only contained 1 of the 3 algal species in this non-choice experiment, a total of 48 replicate containers were used. The containers were submerged in a running seawater aquarium for $48 \mathrm{~h}$, after which all snails were removed and the algal pieces blotted dry and reweighed. Data on the mass of algae consumed in each replicate were adjusted based on growth of algae in the controls. Differences between algal treatments were tested using a Kruskal-Wallis test, followed a posteriori by a nonparametric analogue to Tukey's multiple comparisons procedure (Zar 1984).

Second, given evidence that defensive compounds in algae tend to be concentrated more heavily in meristematic and younger tissues (Phillips \& Towers 1982, Johnson \& Mann 1986, Paul \& Van Alstyne 1987. Hay et al. 1988), we conducted a second experiment to test the effect of algal age on the consumption of Agarum fimbriatum by Tegula pulligo. In addition, because population size and age structures of epiphytic organisms tend to covary with the age of the living substratum (Seed \& O'Connor 1981), we designed this experiment to include colonized and 
cleaned algae as 2 levels of a second factor. Thus, the 4 treatments of $A$. fimbriatum tissue in this 2 -factor experiment were: young colonized, young clean, old colonized, and old clean. Fifteen replicate plastic freezer containers served as the experimental chambers for each treatment, of which 5 were designated as controls for algal growth. Algae for clean treatments were scraped with a stainless steel probe and examined under a dissecting microscope to insure that all macroscopic epiphytic organisms were removed. Algae were blotted dry, weighed, and added to containers with $2 \mathrm{~T}$. pulligo. After $24 \mathrm{~h}$, algae were removed from the containers, blotted dry, and reweighed. After adjusting the data for algal growth in the control replicates, the mass of algae consumed was compared among the 4 treatments using a nonparametric 2-factor ANOVA based on ranks (Zar 1984).

Third, to evaluate the potential risk to Agarum fimbriatum of consumption by Tegula pulligo at our field site, we tested whether snails maintained on diets of different kelp species consume similar amounts of young and old $A$. fimbriatum tissue. Using snails collected exclusively from the surfaces of either $A$. fimbriatum or Macrocystis integrifolia, and maintained on constant diets of these respective algae, this feeding experiment was designed as above, with 2 levels of 2 factors: A. fimbriatum diet and fed young $A$. fimbriatum; $A$. fimbriatum diet and fed old $A$. fimbriatum, $M$. integrifolia diet and fed young $A$. fimbriatum; $M$. inte- grifolia diet and fed old A. fimbriatum. We placed 0.8 to $3.0 \mathrm{~g}$ of young or old A.fimbriatum and $1 \mathrm{~T}$. pulligo into each of 48 containers, with 12 replicates of each treatment. Eight replicates served as controls for algal growth with snails confined in Vexar ${ }^{\mathrm{TM}}$ bags. After submerging the cages in running seawater aquaria and allowing snails to feed for $68 \mathrm{~h}$, the algae were blotted dry and reweighed. As above, these data were analyzed using a nonparametric 2-factor ANOVA (Zar 1984).

\section{RESULTS}

\section{Epiphyte censuses}

The distribution of Lichenopora novae-zelandiae along a blade of Agarum fimbriatum collected during a period of high bryozoan abundance in May 1990 (Durante pers. obs.) showed clear differences in the locations of ancestrulae, juveniles, and adults (Fig. 1). Although random settlement of larvae could have resulted in the observed adult bryozoan distribution (i.e. the algal substratum must have been around long enough for the bryozoans to grow to adult size), newly settled ancestrulae were clearly present in higher numbers on young algal tissue. As ancestrulae bud new zooids to form juvenile colonies, the alga continues to grow, shifting the bryozoans distally along
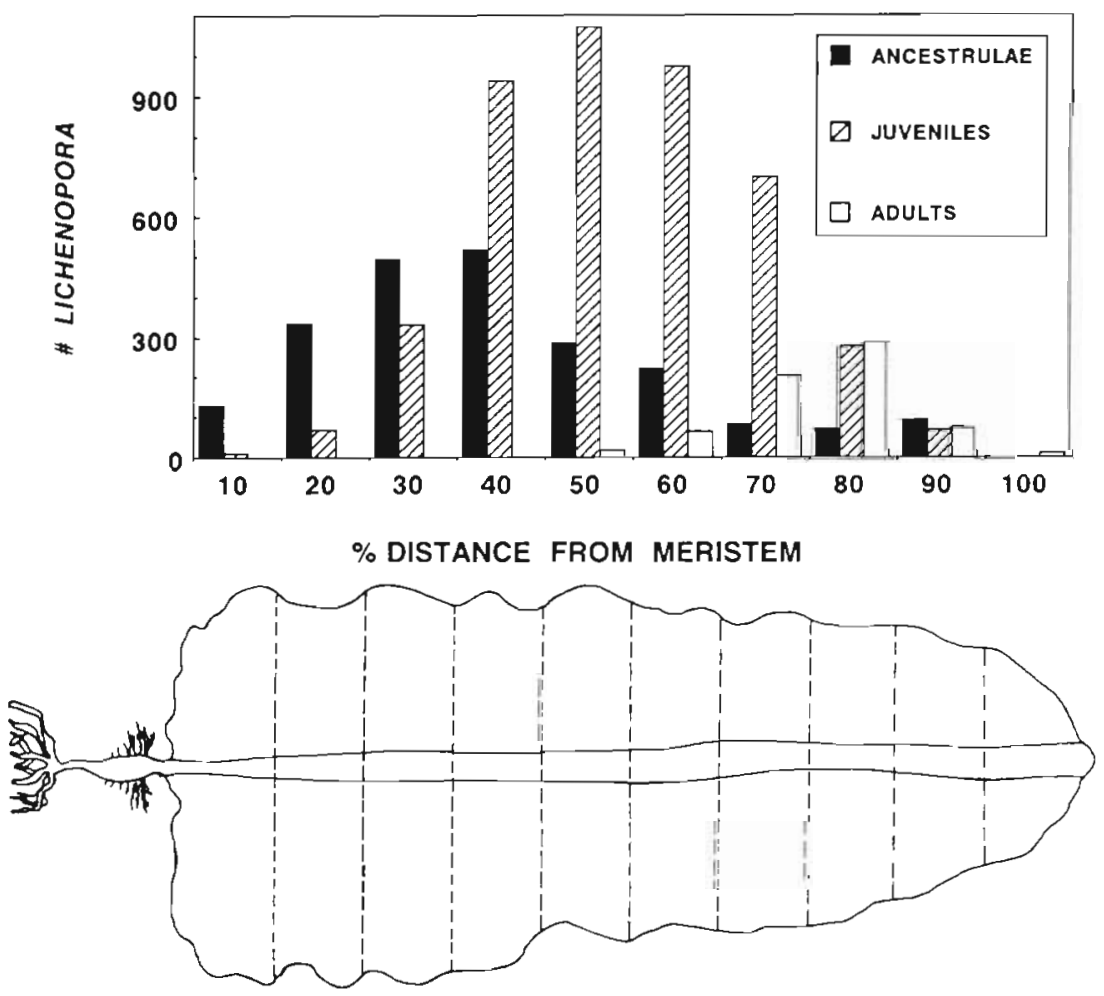

Fig. 1. Lichenopora novae-zelandiae settling on Agarum fimbratum. Positions of newly settled ancestrulae, juvenile colonies, and adult colonies of bryozoans along a frond of kelp, observed during May 1990 
the blade. Considering the dynamics of algal growth (new tissue being added at the intercalary meristem and transported distally) in concert with clonal growth of bryozoans, the location of the juvenile mode halfway between the meristem and the distal tip of the blade simply reflects the distal movement of ancestrulae as they undergo budding and colony formation.

During September 1990, the abundance of adult bryozoan colonies began to decline (Durante pers. obs.), probably due to seasonal senescence and erosion of the distal tips of Agarum fimbriatum blades. The distribution of juveniles and ancestrulae along 10 blades of $A$. fimbriatum was qualitatively the same as that described above for a blade collected during the previous spring (Fig. 2A). In November 1990, when very few adult bryozoans remained on A. fimbriatum, there was no new settlement, yet the algae continued to grow. The resulting distribution of juvenile and adult bryozoans was a concentration of all individuals in the older $50 \%$ of the blade (Fig. 2B).

\section{Bryozoan settlement experiments}

Laboratory experiments testing the choice of settling bryozoan larvae for different species of subtidal algae revealed a high preference for young Agarum fimbriatum tissue over all other choice algae (Fig. 3). After $24 \mathrm{~h}$, the difference in the number of larvae settling among the 4 choice substrata was significantly different (Table 1, Fig. 3A). After

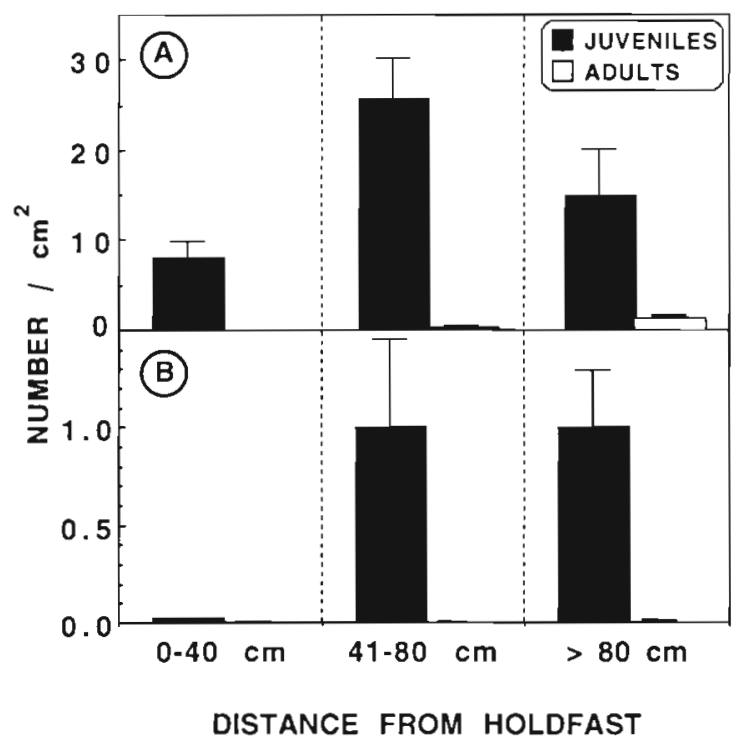

Fig. 2. Lichenopora novae-zelandiae settling on Agarum fimbriatum. Densities of juvenile (including ancestrulae) and adult colonies of bryozoans along fronds of kelp collected during (A) September and (B) November 1990. Data are means $+\mathrm{SE}, \mathrm{n}=10$ plants

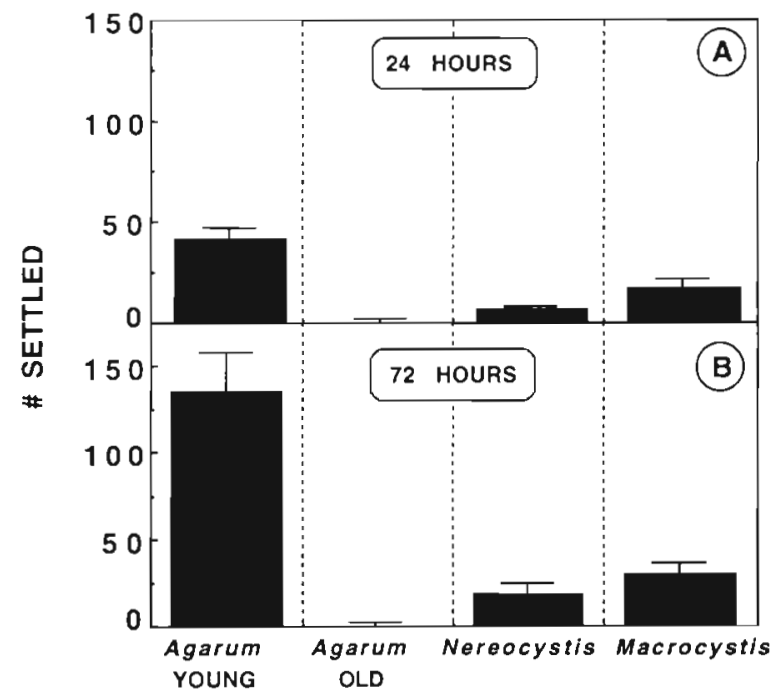

Fig. 3. Settlement preferences of Lichenopora novaezelandiae larvae for 4 algal substrata: young Agarum fimbriatum, old A. fimbriatum, Nereocystis luetkeana and Macrocystis integrifolia. Newly settled ancestrulae were counted (A) after $24 \mathrm{~h}$, and again, (B) after $72 \mathrm{~h}$ from the start of the experiment. Data are means + SE for 10 blocks

Table 1. Friedman's analysis of variance by ranks, applied to settlement of Lichenopora novae-zelandiae larvae on young Agarum fimbriatum, old A. fimbriatum, Nereocystis luetkeana, and Macrocystis integrifolia

\begin{tabular}{|lcccc|}
\hline $\begin{array}{l}\text { Elapsed } \\
\text { time }\end{array}$ & df & $\mathrm{n}$ & $\chi^{2}{ }_{\mathrm{R}}$ & Significance \\
\hline $24 \mathrm{~h}$ & 3 & 10 & $24.212^{\mathrm{a}}$ & $\mathrm{p}<0.001$ \\
$72 \mathrm{~h}$ & 3 & 10 & 24.840 & $\mathrm{p}<0.001$ \\
${ }^{\mathrm{a}} \chi^{2}$ statistic corrected for the presence of tied ranks \\
\hline
\end{tabular}

allowing the remaining competent larvae to settle for an additional $48 \mathrm{~h}$, the high preference for young $A$. fimbriatum tissue became even more evident (Fig. 3B), with a mean of $>133$ larvae settling on the young A. fimbriatum choice in each dish. Again, the Friedman test showed a highly significant difference among the 4 algal choices (Table 1).

\section{Herbivore feeding experiments}

When offered Agarum fimbriatum, Nereocystis luetkeana, or Macrocystis integrifolia as food items, Tegula pulligo consumed significantly different amounts of each algal species (Fig. 4). Consumption of $N$. luetkeana was not significantly different from that of $M$. integrifolia, but both were consumed significantly more than $A$. fimbriatum (Fig. 4).

The experiment testing effects of Agarum fimbriatum age, and presence or absence of epiphytic bryo- 


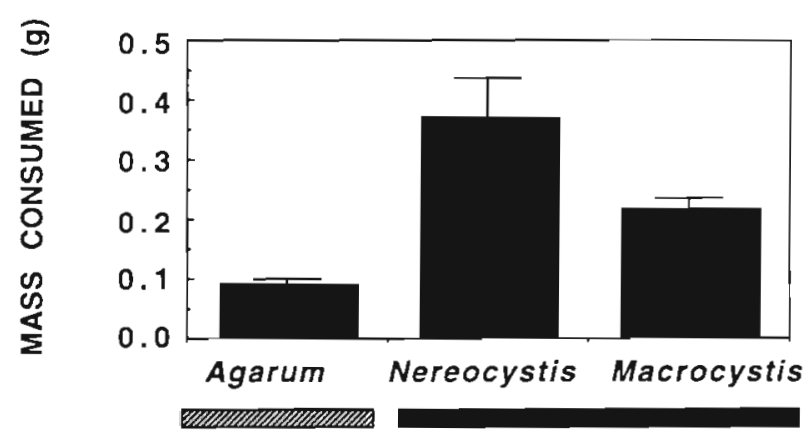

Fig. 4. Mass of Agarum fimbriatum, Nereocystis luetkeana, and Macrocystis integrifolia consumed by Tegula pulligo over 48 h. Data are means + SE of 12 replicates. Prior to analysis, data were adjusted based on mass changes in control algae. Horizontal bars beneath histogram denote separate groups as determined by a nonparametric Tukey-type multiple comparisons procedure

Table 2. Results of a nonparametric-2-factor ANOVA testing effects of Agarum fimbriatum age and colonization by Lichenopora novae-zelandiae on consumption by Tegula pulligo. The test statistic, $H$, is compared with $\chi_{\alpha, d t}^{2}$

\begin{tabular}{|lcccc|}
\hline Source & df & SS & $H$ & Significance \\
\hline Age & 1 & 688.9 & 5.041 & $0.01<\mathrm{p}<0.025$ \\
Colonization & 1 & 828.1 & 6.059 & $0.01<\mathrm{p}<0.025$ \\
Interaction & 1 & 115.6 & 0.846 & $0.25<\mathrm{p}<0.50$ \\
\hline
\end{tabular}

Table 3. Results of a nonparametric 2-factor ANOVA testing effects of algal age and historical diet of Tegula pulligo on consumption of Agarum fimbriatum. The test statistic, $H$, is compared with $\chi^{2}{ }_{\alpha, d i}$

\begin{tabular}{|lrrrl|}
\hline Source & df & SS & H & Significance \\
\hline Age & 1 & 756.9 & 5.538 & $0.10<\mathrm{p}<0.025$ \\
Historical diet & 1 & 207.0 & 1.515 & $0.01<\mathrm{p}<0.25$ \\
Interaction & 1 & 70.2 & 0.514 & $0.75<\mathrm{p}<0.90$ \\
\hline
\end{tabular}

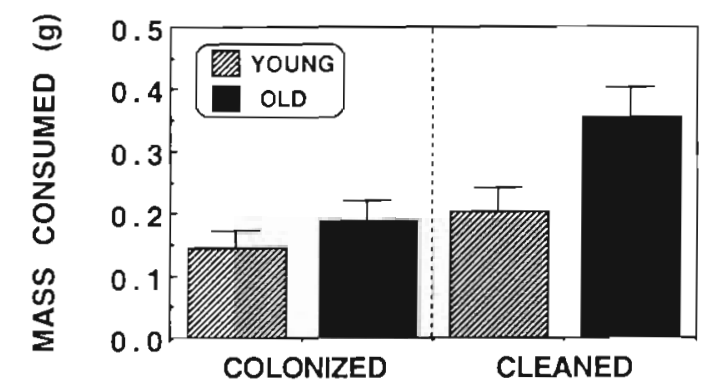

Fig. 5. Agarum fimbriatum consumed by Tegula pulligo. Mass of young (hatched bars) and old (filled bars) kelp consumed by snails over $24 \mathrm{~h}$. Both colonized algae (i.e. algae with resident epiphytic organisms) and cleaned algae were offered to the snails. Data are means + SE of 10 replicates. Prior to analysis, data were adjusted based on mass changes in control algae

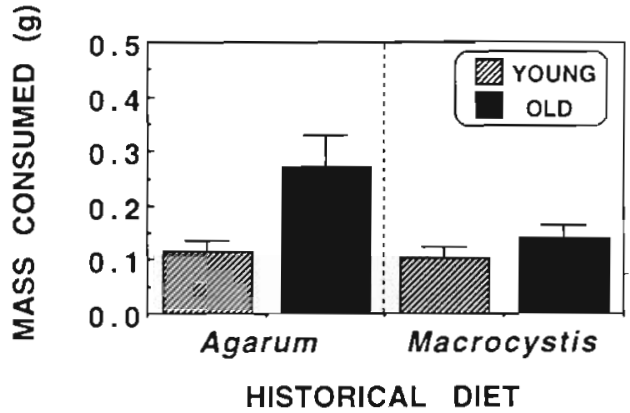

Fig. 6. Agarum fimbriatum consumed by Tegula pulligo. Mass of young hatched bars) and old (filled bars) kelp consumed over 68 h by snails that were raised on diets of either $A$. fimbriatum or Macrocystis integrifolia. Data are means + SE of 10 replicates. Prior to analysis, data were adjusted based on mass changes in control algae

zoans, on consumption of A. fimbriatum by Tegula pulligo showed significant effects of both factors (Table 2). Cleaned $A$. fimbriatum was consumed in higher amounts than colonized A. fimbriatum, and, regardless of the presence of epiphytes, older algae were consumed more than younger algal tissue (Fig. 5).

Algal consumption was influenced by the age of Agarum fimbriatum offered during the experiment but not by the diet on which the Tegula pulligo were maintained in the laboratory prior to experiments (Table 3 ). Although both groups of snails consumed very small quantities of young $A$. fimbriatum tissue $(<0.12 \mathrm{~g}$ in 68 h), snails raised on this alga consumed higher amounts of old A. fimbriatum tissue than did snails raised on Macrocystis integrifolia (Fig. 6).

\section{DISCUSSION}

\section{Adaptive consequences to bryozoans}

Larvae of many sessile invertebrates are known to settle preferentially on substrata where the risk of mortality is low (e.g. Grosberg 1981, Moyse \& Hui 1981. Young \& Chia 1981, Sebens 1983, Johnson \& Strathmann 1989, Young 1989). The association of the bryozoan Lichenopora novae-zelandiae with an algal substratum that is less likely to be consumed by herbivores suggests that the bryozoan may be obtaining refuge from herbivory-related costs, such as loss of habitat, and inadvertent consumption of bryozoan material during grazing. Our substratum selection experiments using $L$. novae-zelandiae larvae clearly show that, regardless of post-settlement factors, active larval choice alone can explain the eventual distributions of this species among algae and along an algal thallus. The actual mechanisms directing these bryozoan larvae to their preferred substratum are currently under 
investigation, yet several lines of evidence lead us to suspect larvae may be responding to differences in anti-herbivore chemical defenses.

Palatability of temperate brown algae to grazers is strongly negatively correlated with levels of polyphenolic compounds, known as phlorotannins (Ragan \& Glombitza 1986). Because Agarum fimbriatum tissues contain among the highest known percentages of total polyphenolics among northeast Pacific brown algae (Steinberg 1985), this feature of the alga's biochemical composition may serve as a beacon for attracting organisms that, for a variety of reasons, may be specialist consumers on $A$. fimbriatum. Plant antiherbivore defenses in terrestrial systems are often exploited by specialist herbivores as cues for locating preferred food (Whittaker \& Feeny 1971). Not only do the larvae of Lichenopora novae-zelandiae prefer settling on a kelp species known to contain unusually high levels of polyphenolic compounds, but they also preferentially select younger tissues, which, together with reproductive structures, are often the most welldefended regions of the alga (Phillips \& Towers 1982, Johnson \& Mann 1986, Paul \& Van Alstyne 1987, Hay et al. 1988).

Although phenolic compounds are thought to have some antifouling properties (Sieburth \& Conover 1965), phenolics in brown algae are contained in sealed vesicles called physodes (Ragan 1976). In the epiphytic association studied here, potential toxic effects of contacting polyphenolic compounds may be minimized by the thick, heavy calcification of Lichenopora novae-zelandiae colonies, as well as by biological membranes surrounding physodes. The absence of large encrusting bryozoan colonies on the surfaces of Agarum fimbriatum in our field surveys may be due to polyphenolic toxicity in organisms with membranous or less heavily calcified body walls, such as the common epiphytic bryozoan Membranipora membranacea. Alternatively, larger encrusting colonies may fracture during expansion of the blade by the superficial meristoderm (Bold \& Wynne 1985), or may simply have insufficient morphological plasticity to adhere to the ruffled and perforated surface of $A$. fimbriatum blades.

\section{Adaptive consequences to algae}

By comparing grazing on colonized and cleaned algae, we revealed the intriguing coevolutionary possibility that Lichenopora novae-zelandiae colonies may offer some protection against herbivory by Tegula pulligo. Although it is generally assumed a priori that epiphytic organisms impose great costs on host algae, very few studies have demonstrated reduced photo- synthetic or growth rates due to the presence of epiphytic organisms (but see Oswald et al. 1984). In fact, an empirical study showed that, although the bryozoan Membranipora tuberculata greatly reduced the incident light reaching photosynthetic tissues of its algal substratum, Gelidium rex, net growth of $G$. rex was unaffected by the presence of bryozoans (Cancino et al. 1987). Factors determining whether epiphytic bryozoans harm or benefit their algal hosts depend not only on the percentage of photosynthetic tissue colonized, but also on the morphology and physiology of the bryozoans themselves. Although our investigation did not include physiological analyses of the epiphytism, any nitrogen limitation in Agarum fimbriatum may in part be alleviated by the absorption of nitrogenous wastes from epiphytic bryozoans. Seasonal pulses in growth rates of the subtidal kelp Laminaria longicruris have been shown to follow peaks in dissolved nitrate in surrounding seawater (Chapman \& Craigie 1977). One study on the interaction between herbivorous zooplankters and their algal prey showed that the increase in algal production due to nitrogen fertilization by herbivores equalled the biomass consumed by herbivores (Sterner 1986).

We noted that the colonial morphology of Lichenopora novae-zelandiae and other stenolaemate bryozoans might render them less harmful epiphytes. Encrusting stenolaemate bryozoans are characterized by relatively small size and heavily calcified body walls (Hayward \& Ryland 1985). Consequently, they are not likely to form sheet-like colonies that cover large percentages of photosynthetic area on host algae. In addition, because these bryozoans remain small in area and relatively prostrate on the algal surface, they probably do not cause increased hydrodynamic drag on the host algae, nor would they render the entire blade more fragile and subject to loss from the stipe, as occurs with heavy fouling (Dixon et al. 1981). The holdfast of Agarum fimbriatum is smaller and less firmly attached to the rock substratum than those of other kelps such as Pterygophora californica, Macrocystis integrifolia, and Eisenia arborea (Durante, pers. obs.), which would render $A$. fimbriatum particularly vulnerable to dislodgment if drag forces were to be increased by epiphyte load.

\section{Concluding remarks}

The association of the epiphytic bryozoan Lichenopora novae-zelandiae with its host algal substratum, Agarum fimbriatum, appears to be adaptively beneficial to the bryozoan by providing a continually renewable substratum that is less likely to be consumed by generalist herbivores. Both the preferential settle- 
ment of $L$. novae-zelandiae larvae on younger regions of $A$. fimbriatum and the avoidance of younger tissues by herbivorous snails support the possibility that this association may be derived from herbivory-related costs. Evidence that the presence of $L$. novae-zelandiae on A. fimbriatum reduced grazing by herbivorous gastropods, an unusual consequence of epiphytism, suggests a possible symbiotic relationship between this small stenolaemate bryozoan and its algal substratum.

Acknowledgements. For providing facilities, equipment, and excellent service, we thank the director and the staff of the Bamfield Marine Station. We are grateful to M. P. DiMarco for assisting us with identifying stenolaemate bryozoans. Discussions with A. A. Benton, L. Gosselin, D. R. Levitan, T. A. Rawlings, and $M$. A. Sewell improved many aspects of experimental design, execution, and writing. K. A. Cook and D. R. Levitan were constant and dependable dive buddies. We especially thank L. D. Druehl for critically reading the manuscript. This work was supported by a grant from NSERC (to F.S.C.), a scholarship from Chevron of Canada (to K.M.D.), and a research assistantship from the Department of Zoology at the University of Alberta (to K.M.D.).

\section{LITERATURE CITED}

Bloom, S. A. (1975). The motile escape response of a sessile prey: a sponge-scallop mutualism. J. exp. mar Biol. Ecol. 17: $311-321$

Bold, H. C., Wynne, M. J. (1985). Introduction to the algae, 2nd edn. Prentice-Hall, Englewood Cliffs

Brancato, M. S., Woollacott, R. M. (1982). Effect of microbial films on settlement of bryozoan larvae (Bugula simplex, $B$. stolonifera and B. turrita). Mar. Biol. $71: 51-56$

Cancino, J. M., Muñoz, J., Muñoz, M., Orellana, M. C. (1987). Effects of the bryozoan Membranipora tuberculata (Bosc.) on the photosynthesis and growth of Gelidium rex Santelices et Abbott. J. exp. mar. Biol. Ecol. 113: 105-112

Chapman, A. R. O., Craigie, J. S. (1977). Seasonal growth in Laminaria longicruris: relations with dissolved inorganic nutrients and internal reserves of nitrogen. Mar. Biol. 40: $197-205$

Davenport, D. (1955). Specificity and behavior in symbioses. Q. Rev. Biol. 30: 29-46

De Burgh, M E., Fankboner, P. V. (1978). A nutritional association between the bull kelp Nereocystis luetkeana and its epizooic bryozoan Membranipora membranacea. Oikos 31: 69-72

Dixon, J., Schroeter, S. C., Kastendiek, J. (1981). Effects of the encrusting bryozoan, Membranipora membranacea, on the loss of blades and fronds by the giant kelp, Macrocystis pyrifera (Laminariales). J. Phycol. 17: 341-345

Geiselman, J. A., McConnell, O. J (1981). Polyphenols in brown algae Fucus vesiculosus and Ascophyllum nodosum: chemical defenses against the marine herbivorous snail, Littorina littorea. J. chem. Ecol. 7: 1115-1133

Greene. R. W. (1970). Symbiosis in sacoglossan opisthobranchs: symbiosis with algal chloroplasts. Malacologia 10: $357-368$

Grosberg, R. K. (1981). Competitive ability influences habitat choice in marine invertebrates. Nature, Lond. 290: $700-702$

Hay, M. E., Paul, V. J., Lewis, S. M., Gustafson, K., Tucker, J., Trindell, R. N. (1988). Can tropical seaweeds reduce herbivory by growing at night?: Diel patterns of growth, nitrogen content, herbivory, and chemical versus morphological defenses. Oecologia 75: 233-245

Hayward, P. J., Ryland, J S. (1985). Cyclostome bryozoans. E. J. Brill \& Dr. W. Backhuys, London

Johnson, C. R., Mann, K. H. (1986). The importance of plant defence abilities to the structure of subtidal seaweed communities: the kelp Laminaria longicruris de la Pylaie survives grazing by the snail Lacuna vincta (Montagu) at high population densities. J. exp. mar. Biol. Ecol. 97 : $231-267$

Johnson, L. E., Strathmann, R. R. (1989). Settling barnacle larvae avoid substrata previously occupied by a mobile predator. J. exp. mar. Biol. Ecol. 128: 87-103

Keough, M. J. (1986). The distribution of a bryozoan on seagrass blades: settlement, growth, and mortality. Ecology 67: 846-857

Larson, B. R., Vadas, R. L., Keser, M. (1980). Feeding and nutritional ecology of the sea urchin Strongylocentrotus drobachiensis in Maine, USA. Mar. Biol. 59: 49-62.

Maki, J. S., Rittschof, D., Schmidt, A. R., Snyder, A. G., Mitchell, R. (1989). Factors controlling attachment of bryozoan larvae: a comparison of bacterial films and unfilmed surfaces. Biol. Bull. mar. biol. Lab., Woods Hole 177 : 295-302

Mihm, J. W., Banta, W. C. Loeb, G. I. (1981). Effects of adsorbed organic and primary fouling films on bryozoan settlement. J. exp. mar. Biol. Ecol. 54: 167-179

Moyse, J., Hui, E. (1981). Avoidance by Balanus balanoides cyprids of settlement on conspecific adults. $J$. mar biol. Ass. U.K. 61: $449-460$

O'Connor, R. J., Seed, R., Boaden, P. J. S. (1979). Effects of environment and plant characteristics on the distribution of Bryozoa in a Fucus serratus L. community. J. exp. mar. Biol. Ecol. 38: 151-178

Olson, R. R. (1983). Ascidian-Prochloron symbiosis: the role of larval photoadaptations in midday larval release and settlement. Biol. Bull. mar. biol. Lab., Woods Hole 165 $221-240$

Osman, R. W., Haugsness, J A. (1981). Mutualism among sessile invertebrates: a mediator of competition and predation. Science 211. 846-848

Oswald, R. C., Telford, N., Seed, R., Happey-Wood, C. M. (1984). The effect of encrusting bryozoans on the photosynthetic activity of Fucus serratus L. Estuar. coast. Shelf Sci. 19: 697-702

Pace, D. R. (1975). Environmental control of red sea urchin (Strongylocentrotus franciscanus) vertical distribution in Barkley Sound, British Columbia. Ph.D. thesis, Simon Fraser University, Burnaby, British Columbia

Paul, V. J., Van Alstyne, K. L. (1987). Chemical defense and chemical variation in some tropical Pacific species of Halimeda (Halimedaceae: Chlorophyta). Coral Reefs 4 263-269

Paul, V. J., Van Alstyne, K. L. (1988). Use of ingested algal diterpenoids by Elysia halimedae Macnae (Opisthobranchia: Ascoglossa) as antipredator defenses. J. exp. mar. Biol. Ecol. 119: 15-29

Phillips, D. W., Towers, G. H. N. (1982). Chemical ecology of red algal bromophenols. I. Temporal, interpopulational and within-thallus measurements of lanosol levels in Rhodomela larix (Turner) C. Agardh. J. exp. mar. Biol. Ecol. 58: 285-293 
Ragan, M. A. (1976). Physodes and the phenolic compounds of brown algae. Composition and significance of physodes in vivo. Botanica mar 19: 145-154

Ragan, M. A., Glombitza, K.-W. (1986) Phlorotannins, brown algal polyphenols. Prog. phycol. Res. 4: 129-241

Reed, C. G. (1987). Phylum Bryozoa. In: Strathmann, M. F. (ed.) Reproduction and development of marine invertebrates of the northern Pacific coast. University of Washington Press, Seattle, p. 494-510

Roland, W. (1980). Epiphytism and endophytism of Macrocystis integrifolia and Nereocystis luetkeana: seasonality, succession and tactics on temporary, living substrate. M.Sc. thesis, Simon Fraser University, Burnaby, British Columbia

Ross, D. M. (1965). Preferential settling on the sea anemone Stomphia coccinea on the mussel Modiolus modiolus. Science 148: 527-528

Ross, D. M. (1971). Protection of hermit crabs (Dardanus spp.) from octopus by commensal sea anemones (Calliactis spp.). Nature, Lond. 230: 401-402

Sebens, K. P. (1983). Settlement and metamorphosis of a temperate soft-coral larva (Alcyonium siderium Verrill) induction by crustose algae. Biol. Bull. mar. biol. Lab., Woods Hole 165: 286-304

Seed, R., O'Connor, R. J. (1981). Community organization in marine algal epifaunas. Ann. Rev. Ecol. Syst. 12: 49-74

Sharp, G. J. (1974). The impact of Tegula pulligo, Gmelin on tissue loss from Macrocystis integrifolia Bory in Barkley Sound, Vancouver Island, British Columbia. M.Sc. thesis.,Simon Fraser University, Burnaby, British Columbia

This article was submitted to the editor
Sieburth, J. M., Conover, J. T (1965). Sargassum tannin, an antibiotic which retards fouling. Nature, Lond. 208: 52-53

Stebbing, A. R. D. (1972). Preferential settlement of a bryozoan and serpulid larvae on the younger parts of Laminaria fronds. J. mar. biol. Ass. U. K. 52: 765-772

Steinberg, P. D. (1984). Algal chemical defense against herbivores: allocation of phenolic compounds in the kelp Alaria marginata. Science 223: 405-407

Steinberg, P. D. (1985). Feeding preferences of Tegula funebralis and chemical defenses of marine brown algae. Ecol. Monogr. 55: 333-349

Sterner, R. W. (1986). Herbivores' direct and indirect effects on algal populations. Science 231: 605-607

Stoner, A. W. (1980). Perception and choice of substratum by epifaunal amphipods associated with seagrasses. Mar Ecol. Prog. Ser. 3: 105-111

Targett, N. M., McConnell, O. J. (1982). Detection of secondary metabolites in marine macroalgae using the marsh periwinkle, Littorina irrorata Say, as an indicator organism. J. chem. Ecol. 8: 115-124

Vadas, R. L. (1977). Preferential feeding: an optimization strategy in sea urchins. Ecol. Monogr. 47: 337-371

Whittaker, R. H., Feeny, P. P. (1971). Allelochemics: chemical interactions between species. Science 171: 757-770

Young, C. M. (1989). Selection of predator-free settlement sites by larval ascidians. Ophelia 30: 131-140

Young, C. M., Chia, F.-S. (1981). Laboratory evidence for delay of larval settlement in response to a dominant competitor. Int. J. Invert. Reprod. Dev. 3: 221-226

Zar, J. H. (1984). Biostatistical analysis, 2nd edn. PrenticeHall, Englewood Cliffs

Manuscript first received: June 22, 1991

Revised version accepted: October 7, 1991 